\title{
O FALACIOSO MONOPÓLIO DA ÚLTIMA PALAVRA ${ }^{1}$
}

\author{
A Constituição é direcionada a todos, não apenas aos juízes \\ Cass Sunstein
}

\author{
Antônio Guimarães Sepúlveda ${ }^{2}$ \\ Carolina Almeida Barbosa ${ }^{3}$
}

\begin{abstract}
Resumo
Intitulando-se árbitro imparcial, o Supremo Tribunal Federal tem declarado reiteradamente que dispõe do monopólio da última palavra. Se, por um lado, tal declaração transparece vivenciarmos a tão propalada supremacia judicial, por outro, evidencia suposto desequilíbrio das relações interpoderes. Diante disso, objetiva-se neste artigo a investigação do sentido e alcance da expressão "monopólio da última palavra" e de como esta se desenvolve num contexto de comunidade de instituições. Ao se ampliar o campo comumente investigado, empreende-se um estudo que, mediante o delineamento da extensão e profundidade da expressão abordada, não se restringe apenas à maneira de como a Suprema Corte compreende o sentido da expressão "última palavra", mas também procura verificar se outros Poderes constituídos também proferem palavras derradeiras acerca de determinadas matérias e sob certas circunstâncias sócio-políticas. Com suporte na teoria institucional e na jurisprudência, conclui-se, ao final, que o Supremo Tribunal Federal deve ser compreendido como guardião constitucional em potência, tendo em vista que a emissão de sua palavra fica subordinada à atuação de outras instituições e à configuração de determinadas circunstâncias sobre as quais exerce pouca ou nenhuma influência.
\end{abstract}

Palavras-Chave: Diálogo Institucional. Comunidade de Instituições. Supremacia Judicial. Separação de Poderes. Deliberação.

\section{INTRODUÇÃO}

A análise e o aperfeiçoamento das instituições públicas nacionais têm exigido dos estudiosos e pesquisadores brasileiros a adoção de referenciais teóricos mais amplos e adaptáveis para o enfrentamento das

\footnotetext{
${ }^{1}$ Este artigo foi elaborado no âmbito do Laboratório de Estudos Teóricos e Analíticos sobre o Comportamento das Instituições (LETACI), vinculado à Faculdade Nacional de Direito e ao Programa de Pós-Graduação em Direito da Universidade Federal do Rio de Janeiro, com financiamento da Fundação Carlos Chagas Filho de Amparo à Pesquisa do Estado do Rio de Janeiro (FAPERJ) e do Conselho Nacional de Desenvolvimento Científico e Tecnológico (CNPq).

${ }^{2}$ Doutorando em Direito pelo Programa de Pós-Graduação da Universidade Estadual do Rio de Janeiro e professor convidado do Programa de Pós-Graduação em Direito Financeiro e Tributário da Universidade Federal Fluminense (UFF), do Programa de Pós-Graduação em Direito Tributário da Fundação Getúlio Vargas (FGV-Rio) e da Escola de Administração Fazendária do Ministério da Fazenda (ESAF).E-mail: agsepulveda@ig.com.br

${ }^{3}$ Mestranda pelo Programa de Pós-Graduação em Direito da Universidade Federal do Rio de Janeiro. Pesquisadora do Laboratório de Estudos Teóricos e Analíticos sobre o Comportamento das Instituições (LETACI). Bolsista de Apoio Técnico à Pesquisa de Nível Superior 1A (CNPq).E-mail: carolina.almb@gmail.com
} 
questões relacionadas com a realidade jurídica nacional. Diferentemente do passado, em que as investigações jurídicas se apegavam predominantemente a temas de alta abstração, hoje, há forte tendência para o desenvolvimento de pesquisas jurídicas mais conectadas com a realidade, com o contexto nacional ${ }^{4}$.

No dinamismo das sociedades contemporâneas, em que a insegurança, a imprevisibilidade e as incertezas aumentam, é notável como as expressões e os conceitos jurídicos, muitos deles outrora inabaláveis, sofrem constantes aperfeiçoamentos ou, até mesmo, profundas reformulações, com vistas a acompanhar as cambiantes dimensões social, política, econômica e institucional. Tanto o surgimento de novas categorias quanto o aperfeiçoamento e reformulação de expressões e conceitos jurídicos, ditos clássicos, denotam a constante necessidade de o Direito estar sempre atento às mudanças do cenário nacional. Esta é a razão de alguns estudiosos afirmarem que o Direito a cada dia se torna menos abstrato e dirige-se a uma dimensão de maior concretude ${ }^{5}$.

Da mesma forma que, num passado recente, já se compreendera amplamente que a Constituição consistia num simples repositório de princípios e regras jurídicas, gerais e abstratas. Nos dias atuais, há quem entenda, por influência do estudo comparado, que a mesma deva ser entendida como um processo de viva participação popular - isto é, como "Constituição viva" ${ }^{-}$ou mesmo como um "sistema de sistemas" (VERMEULE, 2011, p.3).

A despeito de vivenciarmos no País a tão propalada "juristocracia" (HIRSCHL, 2004, p.11) ou, em termos nacionais, a "supremocracia" (VIEIRA, 2007), em que, por omissão ou conveniência (BOLONHA et. al., 2013, p. 6) dos demais Poderes, a intervenção do Poder Judiciário deixa marcas indeléveis de sua atuação institucional, remanesce ainda a nebulosa questão de se saber se essa [aparente] supremacia confere outrossim ao Poder Judiciário a prerrogativa de sempre proferir "a última palavra”, seja em que situação for. Em contraste ao

\footnotetext{
${ }^{4}$ Vale mencionar, exemplificadamente, duas pesquisas que retratam a maior preocupação acadêmica na compreensão e aperfeiçoamento das instituições públicas nacionais. A primeira, realizada pelo Laboratório de Estudos Teóricos e Analíticos sobre o Comportamento das Instituições (LETACI), vinculado à Faculdade Nacional de Direito e ao Programa de Pós-Graduação em Direito da Universidade Federal do Rio de Janeiro, tratou do tema "O Processo Administrativo Disciplinar em uma análise institucional: RFB, INSS e UFRJ” (BRASIL, 2013, p.95-154). A segunda pesquisa, igualmente de enorme importância para o Direito, vem sendo desenvolvida pelo Centro de Justiça e Sociedade (CJUS) da Fundação Getúlio Vargas (FGV - Direito Rio) e intitula-se "Supremo em Números". O Projeto Supremo em Números tem por objetivo produzir conhecimento sobre o papel institucional e o modo de funcionamento do Poder Judiciário e das outras instituições do sistema de justiça.

${ }^{5}$ Afirmação feita pelo Dro Francisco Amaral, professor da Universidade Federal do Rio de Janeiro e presidente da Academia Brasileira de Letras Jurídicas, durante o IX Seminário Ítalo-Ibero-Brasileiro de Estudos Jurídicos realizado no Superior Tribunal de Justiça, intitulado como "A crise da complexidade e o direito". Nesse evento, alegou que o conceito do direito vem passando por profundas transições, superando assim, em larga medida, a concepção de Direito como "conjunto de normas”. Segundo o catedrático, valendo-se da observação de princípios jurídicos, cultura e demais elementos, o Direito caminha para uma dimensão mais concreta. Disponível em <http://www.stj.jus.br/portal_stj/publicacao/engine.wsp?tmp.area=398\&tmp.texto=107898> Acesso em 8 de junho de 2016. Em arremate: "[...] daí dizer que interpretar é construir a partir de algo, por isso significa reconstruir: a uma, porque utiliza como ponto de partida os textos normativos, que oferecem limites à construção de sentidos; a duas, porque manipula a linguagem, à qual são incorporados núcleos de sentido" (ÁVILA, 2005, p. 25).

${ }^{6}$ Um sentido à expressão Constituição viva pode ser encontrada na obra de Bruce Ackerman (ACKERMAN, 2009, p. 552).
} 
pensamento defendido por Häberle ${ }^{7}$ ou por Balkin ${ }^{8}$, a hermenêutica constitucional tradicional, de fundo positivista, a jurisprudência constitucional nacional e parte da doutrina ${ }^{9}$ sugerem que a "última palavra" sobre o sentido e o alcance da Constituição deva sempre caber à Suprema Corte.

As autoridades públicas de alto escalão ${ }^{10}$ fazem coro. E, constantemente, transmitem, por meio de seus pronunciamentos públicos, de forma irrefletida e sem qualquer ressalva, a ideia de que o Supremo Tribunal Federal (STF) detém o "monopólio da última palavra". Não só os membros das instituições republicanas, mas também toda a sociedade brasileira é induzida a pensar que o diálogo institucional ${ }^{11}$ cessa, quando o Supremo Tribunal Federal profere a última palavra.

\footnotetext{
${ }^{7}$ Na obra Hermenêutica Constitucional: a sociedade aberta dos intérpretes da Constituição: contribuição para a interpretação pluralista e "procedimental" da Constituição, escrita em 1975, o estudioso alemão, Peter Häberle defende a ideia, apoiado na teologia do protestantismo alemão, de que toda e qualquer pessoa que leia livremente a Lei Fundamental torna-se co-intérprete das normas constitucionais. Segundo o autor, "o tribunal constitucional nunca deverá arrogar-se o papel de preceptor da nação. O ideal é que ele consiga cooperar com os outros Poderes da República". Entrevista de Peter Häberle disponível em <http://www.conjur.com.br/2011-mai-29/entrevista-peter-haberle-constitucionalista-alemao>. Acesso em 8 de junho de 2016.

${ }^{8}$ Com amparo na noção de "protestantismo constitucional", cunhada por Sanford Levinson, Jack Balkin reafirma a ideia de que nenhuma instituição estatal tenha o monopólio da interpretação da Constituição. (BALKIN, 2011, p. 10).

9 Por todos, cite-se a seguinte passagem: "[...] Outra característica dos atos jurisdicionais é que só eles são suscetíveis de se tornar imutáveis, não podendo ser revistos ou modificados. A Constituição brasileira, como a da generalidade dos países, estabelece que "a lei não prejudicará o direito adquirido, o ato jurídico perfeito e a coisa julgada" (Art. 5, inc. XXXVI). Coisa julgada é a imutabilidade dos efeitos de uma sentença, em virtude da qual nem as partes podem repropor a mesma demanda em juízo ou comportar-se de modo diferente daquele preceituado [...]. No Estado-de-Direito só os atos jurisdicionais podem chegar a esse ponto de imutabilidade, não sucedendo o mesmo com os administrativos ou legislativos. Em outras palavras, um conflito interindividual só se considera solucionado para sempre, sem que se possa voltar a discuti-lo, depois que tiver sido apreciado e julgado pelos órgãos jurisdicionais: a última palavra cabe ao Poder Judiciário". (grifos nossos) (CINTRA, 2009, p. 147, 149, 150, 152 e 337). É ilustrativa a seguinte transcrição: "[...] A opção pela discussão judicial, antes do exaurimento da esfera administrativa, demonstra que o contribuinte desta abdicou, levando o seu caso diretamente ao Poder ao qual cabe dar a última palavra quanto à interpretação e à aplicação do Direito, o Judiciário [...]” (PAULSEN, 2012, p. 519).

${ }^{10} \mathrm{O}$ decano do Supremo Tribunal Federal, Min. Celso de Mello, defendeu, ao apagar das luzes de 2012, o "monopólio da última palavra" em seu voto para que a Câmara dos Deputados apenas declare a perda dos mandatos dos deputados condenados no processo do mensalão. Naquela oportunidade asseverou que é "preciso reafirmar a soberania da Constituição e, em particular, destacar a intervenção e a posição do Supremo Tribunal Federal, que detém em tema de interpretação constitucional e, por força de delegação da Assembléia Constituinte, o monopólio da última palavra". Disponível em <http://exame.abril.com.br/brasil/noticias/celso-de-mello-st-tem-monopolio-da-ultima-palavra . Acesso em 8 de junho de 2016. Em 4 de fevereiro do ano corrente, o Presidente do Supremo Tribunal Federal, Min. Joaquim Barbosa, em resposta ao discurso do ex-presidente da Câmara dos Deputados, o parlamentar Marco Maia, disse que "qualquer assunto que tenha natureza constitucional, uma vez judicializado, a palavra final é do Supremo Tribunal Federal". Disponível em <http://agenciabrasil.ebc.com.br/noticia/2013-02-04/stf-tem-palavra-final-em-assuntos-constitucionais-diz-barbosa >. Acesso em 8 de junho de 2016.

${ }^{11}$ Parafraseando Jean Leclair, a metáfora do diálogo é utilizada para descrever a capacidade de reação de um Poder frente às decisões dos demais, em especial, em temas de natureza constitucional, isto é, em deliberações que veiculem interpretação das disposições constitucionais. Para Leclair, o Judiciário não detém a última palavra e, muito menos, está acima dos demais como um superpoder. Afirma que toda referência ao diálogo só é relevante se promover a participação cidadã nos processos de governança. De acordo com o mencionado autor, se a invocação dialógica serve apenas para legitimar o poder das autoridades públicas, sem levar em conta os interesses dos cidadãos, este é um conceito que não tem nenhum propósito (LECLAIR, 2003, p. 381-382).
} 
Todavia, sob perspectiva sistêmica ${ }^{12}$, parece que o sentido atribuído a essa expressão não condiz precisamente nem com a realidade e, nem muito menos, com a teoria institucional contemporânea. Ainda que cada um dos poderes constituídos, de per si, tenham sido constitucionalmente (re)desenhados ${ }^{13}$ para suprir certa demanda deliberativa dentro de sua própria esfera de competência e expertise, parece razoável supor que, mesmo que atendidas essas expectativas, o simples exercício das respectivas atribuições constitucionais é insuficiente para a constituição e manutenção de um típico Estado Democrático de Direito ${ }^{14}$.

Por meio deste ensaio, não se ambiciona propor um novo conceito jurídico ou a reformulação de determinada categoria jurídica. Não, não se vai tão longe. O propósito deste artigo se circunscreve apenas a analisar, sob uma perspectiva positiva ${ }^{15}$, o sentido e o alcance da afirmação que declara que o Supremo Tribunal Federal "dá a última palavra". Pretende-se, ao final, concluir se outros Poderes podem coordenadamente, in concreto, independentemente da prática retórica do STF, dar a última palavra. Neste estudo, deliberadamente, será privilegiado o exame da noção tecida pelos Ministros da mais Alta Corte do País, num cenário marcado por uma aparente afirmação da supremacia do Poder Judiciário ${ }^{16}$, inserido em uma comunidade de instituições, e de constante redesenho constitucional ${ }^{17}$.

Essa é a temática que motiva o presente trabalho. Precisar o sentido emprestado pelos Ministros da Suprema Corte brasileira à expressão que intitula este artigo e confrontá-lo à perspectiva sistêmico-dialógica. É

\footnotetext{
12 Vermeule utiliza o termo sistema para designar agregados cujas propriedades são determinadas pela interação de seus componentes - tais como, indivíduos, proposições legais e instituições. Esses componentes, em um primeiro nível, são os indivíduos, que se agregam para criar instituições (sistema institucional). E, em um segundo nível, as instituições, ao se interagirem, constituem outro agregado, isto é, "agregados de agregados" (sistema constitucional global). É, em razão disso, que Vermeule afirma que as ordens constitucionais são "sistemas de sistemas" aninhados. As ordens jurídicas são sistemas de dois níveis que emergem a partir das interações estabelecidas entre as instituições para formar uma ordem global. (VERMEULE, 2011, p. 27).

13 A expressão "intervenção institucional" denota o conjunto de medidas necessárias, avaliadas conscientemente, para redefinição intencional de certo desenho - v.g., constitucional - na busca de resultados potencialmente melhores. A partir da verificação de disfunções ou produção de resultados subótimos apurados a partir da análise interna do desenho institucional previamente estabelecido, almeja-se, por meio da intervenção institucional, o delineamento de novo desenho (redesenho institucional), com vistas à obtenção de certo prognóstico, ou seja, de resultados potencialmente melhores. A ocorrência de mudanças circunstanciais significativas, que tornem a regulação normativa defasada e anacrônica, enseja a intervenção do desenhista institucional, no intuito de substituir os mecanismos institucionais que não mais produzem os resultados desejados. (SUNSTEIN, 1990, p.91).

${ }^{14} \mathrm{O}$ liberal legalism - a teoria legal definida pela crença de que os Poderes ou a política podem ser moldados por meio de mecanismos ou desenhos constitucionais - falha em pressupor a submissão dos poderes constituídos ao rule of law. $\mathrm{O}$ rule of law exerce eventuais constrangimentos à ação dos Poderes, porém, crises, emergências e conveniências constitucionais (v.g., delegações, conivência), submetem a interpretação constitucional à discrição do hermeneuta, seja que Poder for. Com relação a essa matéria confira o artigo "A Conveniente Supremacia do Poder Executivo vis-à-vis a Coordenação Constitucional de Poderes". (BOLONHA, 2013, p.5). Disponível em <http://www.publicadireito.com.br/artigos/?cod=eb6bdd281dfc2688> Acesso em 30 de abril de 2016.

${ }^{15}$ Perspectiva positiva ou factual, opondo-se à perspectiva normativa, de natureza subjetiva e valorativa.

${ }^{16}$ A centralidade assumida pelo Poder Judiciário é tema cuja abordagem é recorrente nos estudos do professor Luís Roberto Barroso. (BARROSO, 2009, p.1). Disponível em <http//:www.conjur.com.br/static/text/72894,1> Acesso em 20 de março de 2016.

${ }^{17}$ Vários estudos contemporâneos, tanto no Brasil (SEPULVEDA, 2013, p.2) como no exterior (VERMEULE, 2007, p.4), têm concluído que o rule of law é mecanismo insuficiente para fins de controle mútuo dos poderes constituídos. Nesse aspecto, o rule of law se mostra ineficaz como instrumento único para a implantação do sistema de freios e contrapesos.
} 
demanda que se coloca sob investigação principalmente quando são sensíveis os efeitos causados por essa repetida assertiva no macro contexto de relações interpoderes.

Para essa análise, este artigo se estrutura em outras três partes.

De início, investiga-se sob que noção a Suprema Corte brasileira compreende a afirmação de que detém a competência para declarar terminantemente "a última palavra". Neste primeiro ato, pretende-se explicitar como os Ministros, em seus votos, concebem a definição dessa expressão e em que contexto a mesma é utilizada. Em suma, procura-se inicialmente demarcar o campo semântico da expressão a "última palavra" construída por meio das deliberações tomadas no seio da mais alta Corte, em temas de alta complexidade e suscetíveis de profundos desacordos morais.

Passo seguinte, alguns casos de destaque, com propósitos exemplificativos, submetidos ao crivo do Supremo Tribunal Federal, são analisados. Sob reduzido espectro, considerados os limites deste tipo de abordagem, procurar-se-á verificar se o sentido jurisprudencial conferido pelo Supremo Tribunal à expressão "última palavra" é capaz de abranger alguns casos concretos. Nesse ponto, confronta-se o significado atribuído pelos Ministros à expressão a "última palavra" e determinadas situações concretas, extraídas da jurisprudência do próprio Supremo Tribunal Federal.

A questão que se coloca nesse passo é verificar se há situações concretas reveladoras de que a "última palavra" não foi proferida pelo Supremo Tribunal Federal ou que, a deliberação da Corte foi, em certa medida, superada por decisão de outra instituição republicana partícipe do "sistema de sistemas". Descortina-se, nesta etapa, se a "última palavra" dada pelo Supremo Tribunal Federal molda, em termos absolutos, a atuação dos demais Poderes, incentivando ou desestimulando-os de certa ação, apontando-se hipóteses nas quais (i) o Supremo Tribunal Federal efetivamente dá a "última palavra", (ii) outros tribunais, inclusive com reconhecimento da própria Suprema Corte, devem proferir a palavra final; (iii) o próprio Supremo reconhece que a palavra derradeira compete à instância decisora de outro Poder; (iv) a palavra final da mais alta Corte é superada por pronunciamento de outro Poder ou, por fim, (v) o Supremo não declara palavra alguma.

Por fim, nossas conclusões. A partir dos casos concretos analisados ao longo do artigo, são explicitados, na fase final, os fatores e as causas que motivam afirmar que o Supremo Tribunal Federal não detém o monopólio da última palavra.

Além de se oferecer resposta ao questionamento formulado, espera-se ao final deste artigo que fique ressaltada, sob visão sistêmica, a importância dos diálogos interpoderes para o bom funcionamento do Estado Democrático de Direito ${ }^{18}$. Em síntese, procurar-se-á responder, sob ótica do institucionalismo contemporâneo, se

\footnotetext{
${ }^{18}$ A Constituição de 1988 inova ao incorporar a expressão Estado Democrático de Direito. Ao lado de princípios fundamentais de organização estatal - tais como, a forma federativa e o princípio republicano - o ideal democrático é conjugado ao Estado de Direito, no intuito de salientar as históricas conquistas democráticas, as garantias de caráter legal e o viés social.
} 
toda decisão final proferida pelo Supremo Tribunal Federal tem o condão de inviabilizar o diálogo interpoderes sobre assuntos tidos por relevantes pela sociedade brasileira.

\section{O EMPREGO JURISDICIONAL DA EXPRESSÃO “A ÚLTIMA PALAVRA”}

É natural ao senso comum deduzir, sem maiores aprofundamentos teóricos, que as decisões proferidas pelo Supremo Tribunal Federal, seja como Corte Constitucional - atuando como intérprete constitucional nas ações declaratórias - seja como Suprema Corte - desempenhando o papel de tribunal de última instância resolvam terminantemente todas as demandas e desacordos sociais que possam abalar a paz social, a ordem democrática ou a estabilidade estatal.

A reiterada anunciação de que o Supremo Tribunal Federal é o "guardião da Constituição 19" e, por via de conseqüência, o detentor da "última palavra", se traduz em adjetivação fundamental para afirmação e reafirmação de seu status como poder hegemônico na interpretação constitucional. A constante proclamação pública dessa expressão, livre de qualquer ressalva, tende a incutir a ideia de que a "última palavra" alcança todo e qualquer tema que seja submetido à apreciação do Supremo Tribunal, não ensejando, após a enunciação da palavra derradeira, novos pronunciamentos por parte dos outros poderes, ainda que modificado o contexto em que fora emitida a expressão "última palavra".

Se, por um lado, a incondicional repetição de que o Supremo Tribunal Federal é o detentor da "última palavra" procura reconhecer a hegemonia de sua discricionariedade no relacionamento interpoderes, por outro, pode ser um indício de que o princípio da tripartição de poderes, o mecanismo de freios e contrapesos e a cláusula constitucional da independência e harmonia dos Poderes - em suma, os instrumentos institucionais instalados na Constituição - não conseguem, por si sós, proporcionar a necessária dinâmica dialógica entre os Poderes Republicanos.

O uso, sem reservas, de tal expressão transmite uma noção mais fotográfica (dimensão estática) do que cinematográfica (dimensão dinâmica) do contexto interpoderes, nos induzindo a pensar que sempre que o Supremo Tribunal Federal profere a "última palavra", o diálogo institucional cessa ou, nem mesmo, principia. Atualmente, não são raras as ocasiões em que os próprios Ministros expressam em seus acórdãos que "o monopólio da última palavra”, em matéria de interpretação constitucional, cabe sempre à Corte Suprema, dado que "o modelo político-jurídico vigente em nosso País ${ }^{20 "}$ assim estabeleceu. Tal manifestação ganha maior

\footnotetext{
${ }^{19}$ Com fundamento no caput do artigo 102 da Constituição da República Federativa do Brasil e reafirmado reiteradamente em diversos acórdãos (Em complemento, vide nota 39 deste artigo).

20 "O exercício da jurisdição constitucional, que tem por objetivo preservar a supremacia da Constituição, põe em evidência a dimensão essencialmente política em que se projeta a atividade institucional do Supremo Tribunal Federal, pois, no processo de indagação constitucional, assenta-se a magna prerrogativa de decidir, em última análise, sobre a própria substância do poder. - No poder de interpretar a Lei Fundamental, reside a prerrogativa extraordinária de (re)formulá-la, eis que a interpretação judicial acha-
} vol.10, nº. 03, Rio de Janeiro, 2017.pp. 1349-1369 
significância ao reforçar gradativamente no intelecto social que as decisões que dimanam do Supremo Tribunal Federal são absolutas, isto é, dotadas de caráter definitivo, terminativo, independentemente do contexto considerado.

Pela via da interpretação constitucional, a mais alta Corte, partícipe do concerto institucional, atribui-se paradoxalmente o monopólio da última palavra. No sistema madisoniano, o Supremo Tribunal Federal, que deveria atuar em pé de igualdade perante as demais instituições legislativas e executivas ${ }^{21}$, parece agir como árbitro imparcial, no intuito de impedir a invasão ou o engrandecimento de qualquer departamento estatal. Todavia, a própria jurisprudência do Supremo Tribunal Federal, principalmente aquela consolidada a partir do final dos anos 90, bem como outras deliberações proferidas pelos demais Poderes denotam outro sentido.

Em diversas decisões proferidas pela Suprema Corte brasileira, a expressão "última palavra" é empregada em um sentido mais restrito e, normalmente, acompanhada de expressas ressalvas. Embora recorrentemente utilizada em demandas - quer objetivas ${ }^{22}$, quer subjetivas ${ }^{23}$ - dos mais variados assuntos, vale dizer, direito penal ${ }^{24}$, tributário $^{25}$, previdenciário $^{26}$, eleitoral ${ }^{27}$, constitucional $^{28}$, trabalhista $^{29}$, civil $^{30}$ e processual ${ }^{31}$, dentre outros assuntos

se compreendida entre os processos informais de mutação constitucional, a significar, portanto, que "A Constituição está em elaboração permanente nos Tribunais incumbidos de aplicá-la". Doutrina. Precedentes. - A interpretação constitucional derivada das decisões proferidas pelo Supremo Tribunal Federal - a quem se atribuiu a função eminente de "guarda da Constituição" (CF, art. 102, "caput") - assume papel de fundamental importância na organização institucional do Estado brasileiro, a justificar o reconhecimento de que o modelo político-jurídico vigente em nosso País conferiu, à Suprema Corte, a singular prerrogativa de dispor do monopólio da última palavra em tema de exegese das normas inscritas no texto da Lei Fundamental (STF, MS nº 26.603/DF, rel.: Min. CELSO DE MELLO, Tribunal Pleno. Data de julgamento: 04.10.2007).

${ }^{21}$ Vermeule critica o "julgamento madisoniano" que supõe que o papel adequado dos tribunais, em controvérsias que envolvam a separação dos poderes e a estrutura de governo, deva ser o de impedir a invasão ou o engrandecimento de um poder sobre outro. Para ele, os argumentos do "julgamento madisoniano" falham ao supor que os juízes estão fora do sistema. Parte do pressuposto que não há como o Judiciário ser o regulador da implacável concorrência entre os poderes políticos, uma vez que integra o jogo concertado interpoderes. Contrariamente, Vermeule diz que o desafio do projetista constitucional é precisamente estabelecer, naturalmente, mecanismos institucionais de auto-regulação, apoiado sobre os poderosos motivos de ambição e auto-interesse, ao invés de se fundar sobre o fraco motivo de promoção do bem comum. Segundo Vermeule, o sistema de freios e contrapesos deve surgir endogenamente a partir da concorrência estrutural, ao invés de se apoiar sobre comandos exógenos de um regulador imparcial. (POSNER, 2013, p.7).

${ }^{22}$ Confira STF, ADI n 3345/DF, Relator: Min. CELSO DE MELLO. Data de Julgamento: 23.08.2005.

${ }^{23}$ Confira STF, HC no 80245/MG, Relator: Min. SEPÚLVEDA PERTENCE. Data de Julgamento: 21.06.2000.

${ }^{24}$ Confira STF, HC no 103805/SP, Rel. Min. LUIZ FUX. Data de julgamento: 05/04/2011; HC no 117212/SP, Rel. Min. ROSA WEBER. Data de julgamento: 18.04.2013.

${ }^{25}$ Confira STF, RE no 201160/DF, Rel. Min. MOREIRA ALVES. Data de julgamento: 06.11.2001.

${ }^{26}$ Confira STF, RE no 456689 AgR/SE, rel. Min. JOAQUIM BARBOSA, 2a Turma. Data de julgamento: 31.08.2010.

${ }^{27}$ Confira STF, MS no 26603/DF, Rel. Min. CELSO DE MELLO, Tribunal Pleno. Data de julgamento: 04.10.2007; AI nº 733387/DF, Rel. Min. CELSO DE MELLO, 2a Turma. Data de julgamento: 16.12.2008; RE no 467499/RS, Rel. Min. GILMAR MENDES. Data de julgamento: 07.02.2013.

${ }^{28}$ Confira STF, ADI no 2396/MS, Rel. Min. ELLEN GRACIE, Tribunal Pleno. Data de julgamento: 08.05.2003.

${ }^{29}$ Confira STF, MI no 708/DF, Rel. Gilmar Mendes, Tribunal Pleno. Data de julgamento em 25.10.2007; MI n 670/ES, Rel. Min. Maurício Corrêa, Tribunal Pleno. Data de julgamento: 25.10.2007.

${ }^{30}$ Confira STF, RE no 477554 AGR/MG, Rel. Min. CELSO DE MELLO, 2a Turma. Data de julgamento: 16.08.2011.

${ }^{31}$ Confira STF, AI no 261694 AgR/RS, Rel. Min. MARCO AURÉLIO, Rel. p/acórdão Min. CELSO DE MELLO, 2a Turma. Data de julgamento: 13.03.2001. 
- é comum que tal expressão seja enunciada ao lado de especificações restritivas, tais como: "em matéria de ${ }^{32}$,

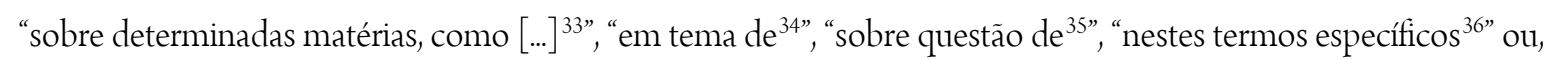
então, "sobre o sentido de ${ }^{37 "}$.

Notável como a menção à expressão "última palavra" ao mesmo tempo que é empregada de forma restrita aos casos que expressamente especifica, alimenta um perfil generalista quando é repetidamente aplicada no cenário judicial. O perfil generalista ganha contornos mais nítidos, quando a citada expressão é indiscriminadamente reverberada no contexto sócio-político ${ }^{38}$.

As decisões proferidas pelos Ministros do Supremo Tribunal Federal ${ }^{39}$, ao expressarem que "a ele é conferido o monopólio da última palavra ${ }^{40}$, fundam-se basicamente em uma racionalidade que se assenta sobre duas premissas centrais, quais sejam: (i) a Constituição está no ápice do ordenamento jurídico brasileiro ${ }^{41}$ e (ii) o Supremo Tribunal Federal é o guardião da Constituição (CF, art. 102, "caput").

\footnotetext{
${ }^{32}$ Confira STF, RE no 477554 AGR/MG, Rel. Min. CELSO DE MELLO, 2a Turma. Data de julgamento: 16.08.2011.

${ }^{33}$ Confira STF, MS no 23452/RJ, Rel. Min. CELSO DE MELLO, Tribunal Pleno. Data de julgamento: 16.09.1999.

${ }^{34}$ Confira STF, HC no 115549 MC/Ba, Rel. Min. CELSO DE MELLO. Data de julgamento: 04.02.2013.

${ }^{35}$ Confira STF, HC no 116532 MC/BA, Rel. Min. ROSA WEBER. Data de julgamento: 31.01.2013.

${ }^{36}$ Confira STF, MS no 23452/RJ, Rel. Min. CELSO DE MELLO, Tribunal Pleno. Data de julgamento: 16.09.1999.

${ }^{37}$ Confira STF, RE no 599633 AgR-AgR/DF, Rel. Min. LUIZ FUX, 1a Turma. Data de julgamento: 02.04.2013.

${ }^{38}$ Em entrevista concedida a repórter do jornal O Estado de São Paulo, no contexto da Operação Satiagraha, o então presidente do STF, Gilmar Mendes, ao comentar o embate travado com o Ministro da Justiça em exercício à época, Tarso Genro, assim se pronunciou: "Não há perdedores nem ganhadores. Temos uma estrutura definida no texto constitucional e cabe ao Supremo guardar e velar pela Constituição em última instância. Ele acerta e erra por último”. Disponível em <http://www.estadao.com.br/noticias/impresso,tarso-nao-tem-competencia-para-opinar,206058,0.htm>. Acesso em 22 de março de 2016. Em cerimônia de abertura dos trabalhos do Ano Judiciário de 2013, o vice-presidente da República, Michel Temer, no plenário do STF e representando a presidenta da República, salientou "a harmonia e independência entre os Poderes Executivo, Legislativo e Judiciário como pilares da democracia brasileira" e "enalteceu o papel do judiciário brasileiro em dar a última palavra sobre o que é ou não lei em nosso país, bem como dos instrumentos jurídicos criados a partir da Constituição Federal de 1988 para dar ao cidadão maneiras de cobrar eventuais omissões do Estado”. Disponível em <http://www2.stf.jus.br/portalStflnternacional/cms/destaquesClipping.php?sigla=port

alStfDestaque_pt_br\&idConteudo=229752>. Acesso em 7 de março de 2016.

${ }^{39} \mathrm{O}$ emprego da expressão "a última palavra” foi e tem sido utilizada por diversos Ministros, dentre aqueles que mais lançaram mão de tal expressão cabe salientar os seguintes magistrados do Supremo Tribunal Federal: Carlos Velloso, Celso de Mello, Ellen Gracie, Gilmar Mendes, Joaquim Barbosa, Luiz Fux, Marco Aurélio, Maurício Correa, Moreira Alves, Nelson Jobim, Rosa Weber, Sepúlveda Pertence, Sidney Sanches e Teori Zavascki.

40 "Incumbe, por isso mesmo, ao Supremo Tribunal Federal, em sua condição institucional de guarda da Constituição (o que lhe confere "o monopólio da última palavra" em matéria de interpretação constitucional), desempenhar função contramajoritária, em ordem a dispensar efetiva proteção às minorias contra eventuais excessos (ou omissões) da maioria, eis que ninguém se sobrepõe, nem mesmo os grupos majoritários, à autoridade hierárquico-normativa e aos princípios superiores consagrados na Lei Fundamental do Estado". Confira em STF, RE no 477554 AGR/MG, Rel. Min. CELSO DE MELLO, 2a Turma. Data de julgamento: 16.08 .2011 .

${ }^{41}$ Relevante contribuição dos pais fundadores da República dos Estados Unidos da América para o Princípio da Separação dos Poderes foi o sistema de freios e contrapesos. Os Federalistas, visando estabelecer o equilíbrio entre os departamentos, alçaram a Constituição à posição altaneira, não conferindo primazia a qualquer dos poderes constituídos. À propósito, cabe mencionar: "We see it particularly displayed in all the subordinate distributions of power, where the constant aim is to divide and arrange the several offices in such a manner as that each may be a check on the other - that the private interest of every individual may be a sentinel over the public rights. These inventions of prudence cannot be less requisite in the distribution of the supreme powers of the State" (MADISON, 1788).
} 
A partir da interpretação constitucional, com base em um marco teórico jusfundamental eminentemente germânico e direcionado à efetividade as normas encartadas na Carta Magna ${ }^{42}$, o Supremo Tribunal Federal estabelece os fundamentos de suas decisões sobre teses como a judicialização da política e a supremacia judicial ${ }^{43}$. Endogenamente, o Supremo interpreta a substância de seu próprio poder ${ }^{44}$, culminando por asseverar que atua na qualidade de "último guardião da Constituição", de detentor da "última palavra".

Os argumentos por meio dos quais o Guardião Constitucional lança mão e justifica sua supremacia ${ }^{45}$ revelam que a singular prerrogativa de dispor do monopólio da "última palavra" decorre de um cenário fotográfico da Constituição, em que a participação de qualquer outra instituição fica excluída, a princípio.

\section{DESCONSTRUINDO A NOÇÃO DO MONOPÓLIO DA ÚLTIMA PALAVRA: ALGUNS CASOS CONCRETOS}

$\underline{\text { Sob perspectiva sistêmica, neste tópico são analisadas várias deliberações dos Poderes Republicanos }}$ com a finalidade de descrever os casos em que: (i) o Supremo Tribunal Federal efetivamente dá a "última palavra", (ii) outros tribunais, inclusive com reconhecimento da própria Suprema Corte, devem proferir a palavra final, (iii) o próprio Supremo reconhece que a palavra derradeira compete à instância decisora de outro Poder, (iv) a palavra final da mais alta Corte é superada por pronunciamento de outro Poder e, por fim, (v) o Supremo não declara palavra alguma.

\section{Casos em que o STF efetivamente dá a "última palavra"}

A expressão "última palavra", dotada de indiscutível caráter de definitividade, pode ser encontrada em

\footnotetext{
${ }^{42}$ A título de exemplo confira os seguintes acórdãos: STF, RMS nº 24.536, Rel. Min. GILMAR MENDES, 2a Turma. Data de Julgamento: 02/12/2003; MS n 24.547/DF, Rel. Min. ELLEN GRACIE, Tribunal Pleno. Data de Julgamento: 14.08.2003; ADI no 3.324/DF, Rel. Min. MARCO AURÉLIO, Tribunal Pleno. Data de Julgamento: 16.12.2004 e ADI nº 3.305/DF, Rel. Min. EROS GRAU, Tribunal Pleno. Data de Julgamento: 13.09.2006.

${ }^{43}$ Originalmente, a tese da judicialização da política foi defendida por Tate e Vallinder (1995). A noção de supremacia judicial, ao contrário, possui registros nos debates políticos Lincoln-Douglas, mas se fortaleceu em precedentes da Suprema Corte norteamericana, como Cooper vs. Aaron, 358 U.S. 1 (1958); e City of Boerne vs. Flores, 521 U.S. 507 (1997) (GRABER, 2006, p. 923).

${ }^{44}$ Vide nota 16.

45 "O exercício da jurisdição constitucional - que tem por objetivo preservar a supremacia da Constituição - põe em evidência a dimensão essencialmente política em que se projeta a atividade institucional do Supremo Tribunal Federal, pois, no processo de indagação constitucional, assenta-se a magna prerrogativa de decidir, em última análise, sobre a própria substância do poder. No poder de interpretar a Lei Fundamental, reside a prerrogativa extraordinária de (re)formulá-la, eis que a interpretação judicial achase compreendida entre os processos informais de mutação constitucional, a significar, portanto, que "A Constituição está em elaboração permanente nos Tribunais incumbidos de aplicá-la". Doutrina. Precedentes. A interpretação constitucional derivada das decisões proferidas pelo Supremo Tribunal Federal - a quem se atribuiu a função eminente de "guarda da Constituição" (CF, art. 102, "caput") - assume papel de essencial importância na organização institucional do Estado brasileiro, a justificar o reconhecimento de que o modelo político-jurídico vigente em nosso País confere, à Suprema Corte, a singular prerrogativa de dispor do monopólio da última palavra em tema de exegese das normas inscritas no texto da Lei Fundamental". Confira ADI no 3.345/DF, Rel. Min. CELSO DE MELLO, Tribunal Pleno. Data de julgamento: 25.08.2005.
} 
vários casos concretos decididos pelo Supremo Tribunal Federal. Na maioria dos casos em que o Supremo efetivamente dá a "última palavra”, é possível identificar alusões diretivas acompanhadas de referenciais, tais como, "em matéria constitucional" ${ }^{46}$ e "pressupostos de reserva de jurisdição" 47 , por meio das quais o Supremo Tribunal Federal traz delimitações contextuais, fundamentalmente fixadas a partir de normas constitucionais de competência, que tendem à edificação de uma argumentação que ratifica o emprego da expressão "última palavra".

Nas demandas judiciais, de um modo em geral, é imprescindível que, em um dado momento, os litígios tenham que ser terminantemente resolvidos, com a finalidade de debelar conflitos intersubjetivos. Por meio de decisão final, alcança-se assim a estabilização da relação conflituosa, a segurança jurídica e a paz social.

Evidencie-se, neste ponto, que, se por um lado, a decisão transitada em julgado - voltada, em regra, para o passado - é imutável, por outro, a interpretação é sempre passível de modificação por meio de uma nova exegese judicial de feição prospectiva ${ }^{48}$. Decisão judicial final em matéria de condenação penal retrata exemplarmente o que se expõe, a exemplo do que aconteceu no curso da Ação Penal no $470^{49}$. A cláusula constitucional da reserva de jurisdição é também um outro bom exemplo. Essa cláusula incide sobre determinadas matérias, tais como, busca domiciliar ${ }^{50}$, interceptação telefônica ${ }^{51}$ e decretação da prisão de qualquer pessoa, ressalvada a hipótese de flagrância ${ }^{52}$.

Nesses assuntos específicos impera a norma jurídica de que assiste exclusivamente ao Poder Judiciário

\footnotetext{
${ }^{46}$ Confira STF, Rcl no 1.203 AgR/BA, Rel. Min. MOREIRA ALVES, Tribunal Pleno. Data de julgamento: 27.09.2000; AI n 245.136/PE, rel. Min. MARCO AURÉLIO. Data de julgamento: 02.08.1999; AI no 253.149 AgR/SP, rel. Min. CELSO DE MELLO. Data de julgamento: 29.02.2000; RE n 268.591/PR, rel. Min. NELSON JOBIM. Data de julgamento: 03.10.2000; AI nº 255.351/RJ. Rel. Min. MARCO AURÉLIO. Data de julgamento: 22.03.2000; AI no 257.018/RJ, rel. Min. MARCO AURÉLIO. Data de julgamento: 22.03.2000; AI n 257.104/RJ, rel. Min. MARCO AURÉLIO. Data de julgamento: 22.03.2000; AI nº 255.454/RJ, rel. Min. MARCO AURÉLIO. Data de julgamento: 13.03.2000; RE no 221.538/SP, rel. Min. SYDNEY SANCHES. Data de julgamento: 28.02.2002; Rcl no 2.986 MC/SE, rel. Min. CELSO DE MELLO. Data de julgamento: 11.03.2005; AI nº 733.387/DF, rel. Min. CELSO DE MELLO, 2a Turma. Data de julgamento: 16.12.2008; RE no 671.228/DF, rel. Min. TEORI ZAVASKI. Data do julgamento: 01.02.2013.

${ }^{47}$ Confira MS no 23.452/RJ, rel. Min. CELSO DE MELLO, Tribunal Pleno. Data de julgamento: 1.09.1999; AI no 252.889/MT, rel. Min. CELSO DE MELLO. Data de julgamento: 10.12.1999; AI no 250.000/SP, rel. Min. MARCO AURÉLIO. Data de julgamento: em 03.11.1999; AI no 255.470/SP, rel. Min. CELSO DE MELLO. Data de julgamento: 01.08.2000; RE $n^{\circ}$ 201.160/DF, rel. Min. MOREIRA ALVES. Data de julgamento: 15.08.2001; RE no 195.745/MG, rel. Min. MOREIRA ALVES. Data de julgamento: 26.02.2002 e AI no 261.694 AgR/RS, rel. Min. CELSO DE MELLO, 2a Turma. Data de julgamento: 13.03.2001.

${ }^{48}$ Exemplar é a lição de Karl Larenz ao afirmar que "[...] na nossa ordem jurídica os tribunais não estão vinculados à interpretação em certa altura aceite. Podem, ou melhor, devem, desviar-se dela quando, segundo a convicção do tribunal, no caso a julgar, melhores razões se inclinam para uma outra interpretação". (LARENZ, 2005, p. 442)

${ }^{49}$ No dia 27 de fevereiro do ano corrente, o Supremo Tribunal Federal, alterando decisão anterior, deliberou, por seis votos a cinco, absolver vários condenados no processo conhecido como o "caso do mensalão". A decisão foi tomada no julgamento dos embargos infringentes - considerados um novo processo que pode efetivamente mudar decisão anterior. Diferentemente da decisão anterior, na recente deliberação seis ministros que votaram pela absolvição entenderam que não ficou configurado o crime de quadrilha. Fator determinante para a alteração da palavra do Supremo foi a nova composição da Corte, que contou em sua composição com a atuação de dois novos integrantes, quais sejam: os Ministros Roberto Barroso e Teori Zavaski.

${ }^{50}$ Confira art. $5^{\circ}$, inc. XI da Constituição da República Federativa do Brasil.

${ }^{51}$ Confira art. $5^{\circ}$, inc. XII da Constituição da República Federativa do Brasil.

${ }^{52}$ Confira art. $5^{\circ}$, inc. LXI da Constituição da República Federativa do Brasil.
} 
(e, ipso facto, ao Supremo Tribunal Federal, que atua como tribunal de recursos) não apenas o direito de proferir a palavra derradeira, mas, sobretudo, a prerrogativa de dizer, desde logo, a primeira palavra. Por força e autoridade do que disciplina o próprio ordenamento jurídico, fica afastada terminantemente a possibilidade de exercício de iguais competências por parte de quaisquer outros departamentos estatais.

Esses exemplos, assim como tantos outros aqui não abordados, indicam que há um amplo setor de atuação em que não se discute se o Supremo Tribunal Federal dá a última palavra sobre determinados temas jurídicos.

\section{Casos em que outros tribunais, inclusive com reconhecimento do STF, dão a última palavra}

Quando os conflitos são resolvidos definitivamente pela instância máxima do Poder Judiciário, robustece-se a noção de que o Supremo Tribunal Federal é o detentor da última palavra. Por outro lado, quando a própria Suprema Corte reconhece ser de competência de outros tribunais a prolação da palavra derradeira, a ideia da aludida expressão perde muito de seu significado. O reconhecimento pelo Supremo de que a palavra final em determinados casos cabe a outros tribunais implica necessariamente reduzir a amplitude da noção de que o Supremo Tribunal Federal é o detentor da palavra final.

De início, cite-se, como exemplo, o RE no $456.689 \mathrm{AgR} / \mathrm{SE}^{53}$. Nesse caso, foi analisada a questão concernente à possibilidade de acumulação de pensão especial e benefício previdenciário por parte de militar.

No julgamento do citado recurso extraordinário, o relator designado para a feitura do acórdão entendeu que o caso cuidava eminentemente de matéria de cunho legal e que os autos careciam de provas que ratificassem a qualidade de ex-combatente. Segundo a ótica do colegiado, não caberia àquela instância o enfrentamento de tais matérias, sob pena de ofensa à competência recursal extraordinária. Sob tal entendimento e considerando tratar-se de matéria de cunho legal, foi reconhecida a competência do Superior Tribunal de Justiça para anunciar a "última palavra" no caso sub judice e, incontinenti, determinou-se o retorno dos autos à instância de origem.

Merece destaque, a essa altura, a pacífica jurisprudência da Suprema Corte no sentido de declarar a inadequação de interposição de recurso extraordinário quando a alegada ofensa envolva reapreciação de interpretação de normas infraconstitucionais dada pelo Superior Tribunal de Justiça ${ }^{54}$.

Outro exemplo que se aduz neste tópico é o Habeas Corpus nº 103.805/SP, julgado em 2011. Nesse outro caso, o relator, Ministro Luiz Fux, considerou ser a apelação um instrumento para aplicação do duplo grau

\footnotetext{
${ }^{53}$ Confira STF, RE 456.689 AgR/SE, rel. Min. JOAQUIM BARBOSA, 2a Turma. Data de julgamento: 31.08.2010.

${ }^{54}$ Segundo o Min. Ricardo Lewandowski, com a negativa de provimento ao recurso especial pelo Superior Tribunal de Justiça tornaram-se definitivos os fundamentos infraconstitucionais que amparam o acórdão recorrido (Súmula 283 do STF) [...]” (STF, AI no 842.496 AgR/RS, rel. Min. RICARDO LEVANDOWSKI, $1^{\text {a }}$ Turma. Data de julgamento: 14.06.2001.
} 
de jurisdição. Na oportunidade, o Ministro esclareceu que um juiz togado não pode substituir o corpo de jurados, quando necessária a aferição da "última palavra" em circunstância de crime doloso. Sinteticamente, o Ministro Luiz Fux asseverou que, havendo erro por parte do juiz togado, é cabível ao Tribunal Popular proferir a última decisão de caráter satisfativo.

Embora a introdução da Ação de Descumprimento de Preceito Fundamental no ordenamento tenha ocorrido a posteriori da jurisprudência que se traz à colação, não deixam de ter importância, para fins acadêmicos, os casos concretos aos quais não se asseguravam o efetivo, mas apenas o potencial, controle de constitucionalidade. Antes da referida e significativa alteração do conjunto de mecanismos de controle de constitucionalidade, o Supremo Tribunal Federal reconhecia que, na hipótese ora tratada, outra instância decisora deveria proferir a última palavra:

O nosso sistema constitucional não admite o controle concentrado de constitucionalidade de lei ou ato normativo municipal em face da Constituição Federal; nem mesmo perante o Supremo Tribunal Federal que tem, como competência precípua, a sua guarda, art. 102.

O único controle de constitucionalidade de lei e de ato normativo municipal em face da Constituição Federal que se admite é o difuso, exercido 'incidenter tantum', por todos os órgãos do Poder Judiciário, quando do julgamento de cada caso concreto ${ }^{55}$. (grifos nossos) $)^{56}$

Nessas hipóteses, há grande possibilidade da última palavra ser proferida por outra instância judicial, desde que a matéria controvertida não seja alçada à Suprema Corte.

Por meio desses casos concretos, constata-se que há situações em que o próprio Supremo Tribunal Federal, como guardião constitucional das normas jurídicas inscritas na Lei Fundamental, declara, fotográfica e expressamente, que outros tribunais pátrios, partícipes da comunidade de instituições, detêm a competência para proferir a palavra final em determinadas hipóteses ${ }^{57}$.

\footnotetext{
${ }^{55}$ Confira STF, Rcl no 337/DF, rel. Min. PAULO BROSSARD, Tribunal Pleno. Data de julgamento: 18.08.1994.

${ }^{56}$ As seguintes decisões exemplificam a sólida jurisprudência do Supremo Tribunal Federal no sentido de que o desenho constitucional brasileiro não admite o controle de constitucionalidade concentrado de lei e de ato normativo municipal em face da Constituição Republicana: " [... ] Se a base da ação direta de inconstitucionalidade em trâmite no Tribunal de Justiça do Estado do Paraná é a declaração de inconstitucionalidade de lei municipal em face da Carta Federal, impõe-se declarar extinta a ação direta, por exorbitar da competência da Corte reclamada [...]” (RTJ 174/3, Rel. Min. ILMAR GALVÃO, Pleno). “[...] É pacífica a jurisprudência do Supremo Tribunal Federal, antes e depois de 1988, no sentido de que não cabe a tribunais de justiça estaduais exercer o controle de constitucionalidade de leis e demais atos normativos municipais em face da Constituição Federal [...]" (RTJ 200/636, Rel. Min. JOAQUIM BARBOSA, Pleno).

${ }^{57}$ Os casos de inconstitucionalidades reflexas ou imediatas são casos que igualmente o Supremo Tribunal Federal se furta de apreciar. Confira, por todos o ADI no 3.190/GO, rel. Min. SEPÚLVEDA PERTENCE, Tribunal Pleno. Data de julgamento: 05.10.2006, p. 60.
} 


\section{Casos em que o STF reconhece que a última palavra cabe a instância decisora de outro Poder}

Igualmente, destacam-se julgados em que o pronunciamento da Suprema Corte direciona-se ao reconhecimento de que a última palavra compete a instâncias decisoras de outro Poder.

Exemplo do que se afirma está retratado na $\mathrm{ADI} \mathrm{n}^{\circ} 2.396 / \mathrm{MS}^{58}$, no qual se verifica explícita manifestação no sentido de que não compete ao Supremo Tribunal Federal se manifestar sobre as propriedades técnicocientíficas do amianto e dos riscos de sua utilização para a saúde da população. A principal questão que circundava a ADI no 2.396/MS dizia respeito à verificação da constitucionalidade de vários dispositivos da Lei no 2.210, de 2001, editada pelo Estado do Mato Grosso do Sul, e que regulava, dentre outros aspectos, a proibição de fabricação, ingresso, comercialização e estocagem de amianto ou de produtos à base de amianto destinados à construção civil.

No caso enfrentado, a Corte Constitucional ao mesmo tempo que reconheceu sua incompetência para se manifestar sobre aspectos técnico-científicos ${ }^{59}$, limitou-se a analisar o contraste e a disparidade existentes entre a Lei editada pelo Estado do Mato Grosso do Sul e os parâmetros constitucionais. Nesse sentido, deixou assente que o ente político estadual excedeu a margem de competência concorrente que lhe é assegurada para legislar sobre produção e consumo, proteção do meio ambiente e controle de poluição e proteção e defesa da saúde.

Outro exemplo merecedor de destaque é o conhecido caso Cesare Battisti ${ }^{60}$.

Com o pedido de extradição apresentado pelo Estado italiano para que o Brasil entregasse o ex-militante que aqui se refugiou, coube ao Supremo Tribunal Federal deliberar se o deferimento da extradição vinculava o Presidente da República. Uma vez mais, de maneira explícita, houve manifestação do Pretório Excelso no sentido de que a última palavra caberia a outro Poder, que não a Suprema Corte. Por se tratar de uma decisão diretamente conectada ao exercício da soberania brasileira, em sua feição externa, determinou-se que a decisão pertencia exclusivamente ao Presidente da República.

No campo da soberania, relativamente à extradição, é assente que o ato de entrega do extraditando é exclusivo, de competência indeclinável do Presidente da República, conforme consagrado na Constituição, nas Leis, nos Tratados e na própria decisão do Egrégio Supremo Tribunal Federal proferida no curso do processo de

\footnotetext{
${ }^{58}$ Confira STF, RE 456.689 AgR/SE, rel. Min. JOAQUIM BARBOSA, 2a Turma. Data de julgamento: 31.08.2010.

${ }^{59}$ A Min. Ellen Gracie, no julgamento da ADI no 2.396/MS, pontuou nos seguintes termos: "[c]onforme ressaltei no julgamento cautelar, não cabe a esta Corte dar a última palavra a respeito de propriedades técnico-científicas do elemento em questão e dos riscos de sua utilização para a saúde da população. Os estudos nesta seara prosseguem e suas conclusões deverão nortear as ações das autoridades sanitárias. O que nos compete verificar é a ocorrência de contraste inadmissível entre a lei em exame e o parâmetro constitucional [...]" (grifos nossos)
} 
Extradição no 1.085 . No que tange ao tema extradição, ao Supremo Tribunal Federal cumpre apenas analisar a legalidade e a procedência do pedido. Assim, se indeferida a solicitação, deixa-se de constituir o título jurídico sem o qual o Presidente da República não pode efetivar a extradição. Caso contrário, isto é, se deferida, a entrega do súdito ao Estado requerente fica a critério discricionário do Presidente.

Os casos ora analisados demonstram que, de fato, a palavra final não é dada pelo Supremo Tribunal Federal em todo e qualquer tema submetido a sua apreciação.

\section{Casos em que a palavra final da mais alta Corte é superada por pronunciamento de outro Poder}

Vários casos envolvendo matéria tributária são exemplares para os propósitos deste tópico. Dentre esses, vale mencionar o caso do imposto sobre propriedade predial e territorial urbana (IPTU) ${ }^{61}$; os casos das taxas de iluminação pública ${ }^{62}$ e da contribuição para o custeio do serviço de iluminação pública (COSIP); o caso do imposto sobre operações relativas à circulação de mercadorias e sobre prestação de serviços de transporte interestadual e intermunicipal e de comunicação (ICMS) ${ }^{63}$ incidente sobre a importação de bens e mercadoria por pessoas físicas e, por fim, o caso da contribuição previdenciária incidente sobre os proventos de aposentadorias e pensões concedidas pelo regime próprio dos servidores públicos ${ }^{64}$.

Ressalte-se que, em todos os mencionados casos, a aprovação de emenda constitucional pelo Poder Legislativo foi o instrumento institucional utilizado para fins de superação da palavra proferida pelo Supremo Tribunal Federal. Embora as decisões da instância máxima do Poder Judiciário tenham permanecido incólumes, por meio da edição de emendas constitucionais superou-se a palavra, o entendimento emanado pelo Supremo.

No caso do IPTU, imposto de natureza real, o Congresso Nacional alterou a redação do artigo 156 da Constituição Republicana ${ }^{65}$, por meio da Emenda Constitucional n 29, de 2000, a fim de possibilitar a instituição

\footnotetext{
${ }^{60}$ Confira STF, Rcl no 11.243/República Italiana, rel. Min. GILMAR MENDES, rel. p/acórdão Min. LUIZ FUX. Data de julgamento: 08.06.2011.

${ }^{61}$ Confira STF, Rcl no 11.243/República Italiana, rel. Min. GILMAR MENDES, rel. p/acórdão Min. LUIZ FUX. Data de julgamento: 08.06.2011.

${ }^{62}$ Confira STF, RE no 233.332/RJ, Rel. Min. ILMAR GALVÃO. Data de julgamento: 10/03/1999; STF, AI no 588.248 AgR/RJ, Rel. DIAS TOFFOLI. Data de julgamento: 14/02/2012.

${ }^{63}$ Confira STF, RE 203.075/DF, Rel. Min. ILMAR GALVÃO, Rel. p/acórdão Min. MAURÍCIO CORREA. Data de julgamento: 05/08/1998.

${ }^{64}$ Confira STF, ADI no 2.010/DF, Rel. Min. CELSO DE MELLO, Tribunal Pleno. Data de julgamento: 30.09.1999. As alterações promovidas pela Emenda Constitucional no 41, de 2003, sobre o artigo 40 da Constituição da República Federativa do Brasil, objetivaram superar a decisão proferida no curso da $\mathrm{ADI}$ n $2.010 / \mathrm{DF}$.

${ }^{65}$ Constituição Republica, de 1988: [...] Art. 156. Compete aos Municípios instituir impostos sobre: [...] $\underline{\text { I-propriedade predial e }}$ territorial urbana; [...] $₫ 1^{\circ}$ Sem prejuízo da progressividade no tempo a que se refere o art. $182, \$ 4^{\circ}$, inciso II, o imposto previsto no inciso I poderá: (Redação dada pela Emenda Constitucional no 29, de 2000) I - ser progressivo em razão do valor do imóvel; e (Incluído pela Emenda Constitucional no 29, de 2000) II - ter alíquotas diferentes de acordo com a localização e o uso do imóvel. (Incluído pela Emenda Constitucional no 29, de 2000) (grifos nossos)
} 
do IPTU progressivo em razão do valor venal do imóvel. A alteração constitucional teve por objetivo superar deliberação do Supremo que assentara que a fixação de alíquotas progressivas somente poderia se dar, à vista da moldura constitucional vigente à época, para fins de cumprimento da função social da propriedade (finalidade extrafiscal), jamais sob a perspectiva estritamente fiscal, vale dizer, estritamente arrecadatória.

Em outra ocasião, como o Supremo Tribunal Federal houvera declarado inconstitucionais várias taxas de iluminação pública ${ }^{66}$, "visto que possuíam fato gerador inespecífico, não mensurável, indivisível e insuscetível de ser referido a determinado contribuinte", a Emenda Constitucional no 39, de $2002^{67}$, veio ao mundo jurídico para permitir que os municípios criassem contribuições para o custeio do serviço de iluminação pública (COSIP) em substituição às taxas que foram declaradas inválidas. Por meio desse instrumento normativo, o Poder Legislativo autorizara os Municípios que instituíssem o novel tributo e pudessem angariar os recursos financeiros necessários para manutenção do essencial serviço de iluminação pública ${ }^{68}$.

Igual desfecho teve o caso do ICMS na importação praticada por pessoa física. À época, a Suprema Corte decidiu que a pessoa natural, por não se qualificar como comerciante, não praticaria atos de natureza mercantil. Não caracterizada a circulação de mercadoria, fato necessário e suficiente para a incidência do ICMS, inexigivel seria o imposto quando se tratasse de importação de bem importado por pessoa física. Tal qual nos casos anteriores, a superação de tal deliberação veio por meio da Emenda Constitucional no 33, de $2001^{69}$.

É de se concluir que a emenda constitucional é instrumento dialógico institucional, típico de superação de determinadas deliberações do Supremo Tribunal Federal ${ }^{70}$. Frequentemente as emendas constitucionais têm

\footnotetext{
${ }^{66}$ A teor do artigo 145 da Constituição combinado com o artigo 77 do Código Tributário Nacional - Lei no 5.172, de 1966 -, as taxas têm como fato gerador o exercício regular do poder de polícia, ou a sua utilização, efetiva ou potencial, de serviços públicos específicos e divisíveis, prestados ao contribuinte ou postos a sua disposição. Segundo o entendimento do Supremo Tribunal Federal, a incompatibilidade das leis municipais instituidoras de taxas de iluminação pública e a Constituição é patente. O serviço de iluminação pública por se revelar inespecífico e indivisível não pode ser custeado por meio de taxas, ainda que a arrecadação tributária seja imprescindível aos cofres públicos.

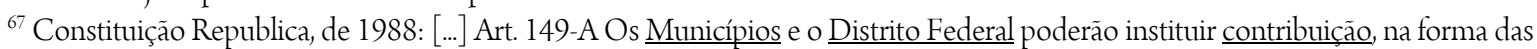
respectivas leis, para o custeio do serviço de iluminação pública, observado o disposto no art. 150, I e III. (Incluído pela Emenda Constitucional no 39, de 2002) Parágrafo único. É facultada a cobrança da contribuição a que se refere o caput, na fatura de consumo de energia elétrica. (Incluído pela Emenda Constitucional no 39, de 2002) [...] (grifos nossos).

${ }^{68}$ Parte da doutrina nacional entende que a EC no 39, de 2002, é verdadeira correção legislativa cujos objetivos são meramente arrecadatórios.

${ }^{69}$ Art. 155. Compete aos Estados e ao Distrito Federal instituir impostos sobre: [...] II - operações relativas à circulação de mercadorias e sobre prestações de serviços de transporte interestadual e intermunicipal e de comunicação, ainda que as operações e as prestações se iniciem no exterior; [...] $₫ 2{ }^{\circ} \mathrm{O}$ imposto previsto no inciso II atenderá ao seguinte: (Redação dada pela Emenda Constitucional no 3, de 1993) [...]IX - incidirá também:[...] a) sobre a entrada de bem ou mercadoria importados do exterior por pessoa física ou jurídica, ainda que não seja contribuinte habitual do imposto, qualquer que seja a sua finalidade, assim como sobre o serviço prestado no exterior, cabendo o imposto ao Estado onde estiver situado o domicílio ou o estabelecimento do destinatário da mercadoria, bem ou serviço; (Redação dada pela Emenda Constitucional no 33, de 2001) [...] (grifos nossos)

${ }^{70}$ Vermeule e Posner sugerem que não é o constituinte derivado, as doutrinas judiciais ou mesmo as emendas constitucionais que promovem, como mecanismos centrais, as mudanças constitucionais. Entendem os referidos estudiosos que as modificações constitucionais derivam do embate travado entre as instituições: We suggest that the central mechanism of constitutional change is not amendments, higher lawmaking, or even judicial doctrine, but episodes of conflict between institutions over the distribution of
} vol.10, no. 03, Rio de Janeiro, 2017.pp. 1349-1369 
sido utilizadas como meio de resposta do Poder Executivo e do Legislativo às decisões do Supremo Tribunal Federal $^{71}$. Inclusive, o próprio Tribunal admite a emenda constitucional como meio de revisão do sistema global vigente $^{72}$.

\section{Casos em que o STF não dá palavra alguma, seja em decorrência de falta de provocação ou por falhas do ordenamento jurídico}

Há casos que não são judicializáveis e, por consequência, não chegam ao conhecimento do "guardião da Constituição".

A evidência do que se afirma pode ser bem exemplificado a partir da Súmula do Conselho Administrativo de Recursos Fiscais $(\mathrm{CARF})^{73} \mathrm{n}^{\circ} 2$ que declara a incompetência daquele tribunal administrativo para manifestar-se sobre inconstitucionalidades de lei tributária.

Em razão da gravidade dos pronunciamentos outrora emitidos pela Administração Tributária judicante acerca da constitucionalidade de determinadas normas tributárias, o Conselho Administrativo de Recursos Fiscais deliberou, já na vigência do artigo 26-A do Decreto n 70.235 , de 6 de março de $1972^{74}$, editar a Súmula nº 2 , a fim

policymaking authority. Constitutional change is a special kind of politics, one that emerges from institutional struggle in a twilight world without clear or settle rules. This process is far removed from the clear rule of law that is central to liberal legalism. Constitutional law is pervasively shaped by (what the headlines call) "showdowns" between and among branches of government (POSNER, 2010, p. 67).

${ }^{71}$ Sob mesma linha de compreensão de Vermeule (2007, p. 24) não entendemos que a simples publicação de determinada emenda constitucional necessariamente promova os efeitos desejados. Somente a dinâmica institucional poderá revelar os efeitos emergentes decorrentes de sua introdução no ordenamento jurídico. A emenda, em tradução livre, deve "ser colocada em uso e se mostrar eficaz em ordem a moldar a conduta dos demais" (VERMEULE, 2007, p. 26).

72 É dever rememorar a irrepreensível observação do eminente Ministro Gilmar Mendes $(1999,503)$ em que apresenta considerações de irrecusável pertinência quanto ao tema exposto: [...] É que as decisões da Corte Constitucional estão inevitavelmente imunes a qualquer controle democrático. Essas decisões podem anular, sob a invocação de um direito superior que, em parte, apenas é explicitado no processo decisório, a produção de um órgão direta e democraticamente legitimado. Embora não se negue que também as Cortes ordinárias são dotadas de um poder de conformação bastante amplo, é certo que elas podem ter a sua atuação reprogramada a partir de uma simples decisão do legislador ordinário. Ao revés, eventual correção da jurisprudência de uma Corte Constitucional somente há de se fazer, quando possível, mediante emenda. Essas singularidades demonstram que a Corte Constitucional não está livre do perigo de converter uma vantagem democrática num eventual risco para a democracia. Assim como a atuação da jurisdição constitucional pode contribuir para reforçar a legitimidade do sistema, permitindo a renovação do processo político com o reconhecimento dos direitos de novos ou pequenos grupos e com a inauguração de reformas sociais, pode ela também bloquear o desenvolvimento constitucional do País. O equilíbrio instável que se verifica e que parece constituir o autêntico problema da jurisdição constitucional na democracia afigura-se necessário e inevitável. Todo o esforço que se há de fazer é, pois, no sentido de preservar o equilíbrio e evitar disfunções [...] (grifos nossos).

${ }^{73}$ Sucedendo o antigo Conselho de Contribuintes, o Conselho Administrativo de Recursos Fiscais (CARF) foi criado pela Medida Provisória no 449, de 3 de dezembro de 2008, convertida na Lei no 11.941, de 27 de maio de 2009, e instalado pelo Excelentíssimo Senhor Ministro de Estado da Fazenda em 15 de fevereiro de 2009, mediante Portaria MF no 41, de 2009. É órgão colegiado, paritário, integrante da estrutura do Ministério da Fazenda e tem por finalidade julgar, em última instância administrativa, recursos de ofício e voluntário de decisão de primeira instância, bem como os recursos de natureza especial, que versem sobre a aplicação da legislação referente a tributos administrados pela Secretaria da Receita Federal do Brasil.

${ }^{74}$ O Decreto no 70.235 , de 1972, regula o processo administrativo fiscal na esfera federal. Quanto ao ponto é importante evidenciar que a norma inscrita no artigo 26-A do Decreto no 70.235, de 1972, é fruto da conversão da Medida Provisória no 449, de 2008, e vigia anteriormente à edição da Súmula CARF no 2 . 
de declarar que aquela instância administrativa "não é competente para se pronunciar sobre a inconstitucionalidade de lei tributária" ${ }^{75}$. A edição da Súmula CARF no 2 se apoiou em acórdãos exarados em um interregno de aproximadamente cinco anos ${ }^{76}$, período esse que certamente não delimita o lapso temporal em que diversas declarações de inconstitucionalidade foram proferidas no curso do contencioso administrativo.

A prolação de diversas declarações de inconstitucionalidade em matéria tributária por parte de um tribunal administrativo evidencia a gravidade de uma situação que culminou na publicação de uma regra jurídica insculpida na Medida Provisória no 449, de 2008, e da própria súmula administrativa. As decisões administrativas que declararam (e ainda declaram) inconstitucionalidades de normas da legislação tributária demonstram que órgãos administrativos usurparam (e talvez ainda usurpem) a singular prerrogativa do Supremo Tribunal Federal "de dispor do monopólio da última palavra em tema de exegese das normas inscritas no texto da Lei Fundamental". A afirmação que se faz não é descabida, pois decisões administrativas de sedimentação tributária negaram (e continuam a negar) vigência ou decretaram (e continuam a decretar ${ }^{77}$ ) inconstitucionalidades de normas jurídicas vigentes e presumivelmente válidas.

Evidencie-se igualmente outros casos em que o próprio sistema jurídico adota soluções que impedem a atuação do Supremo Tribunal Federal na qualidade de guardião da Constituição.

A jurisprudência pátria, mais uma vez, nos apresenta um caso exemplar. No REsp no $1.415 .033 / \mathrm{RS}^{78}$, a sentença que afastara a cobrança do Imposto sobre Serviços de Qualquer Natureza (ISS) incidente sobre atividades notariais e registrais fora restabelecida em razão da ocorrência da coisa julgada em momento anterior ao pronunciamento do Tribunal local. Os Ministros do Tribunal da Cidadania vislumbraram que a sentença transitada em julgado não poderia ter sido reformada, ainda que o acórdão do Tribunal de Justiça do Estado do Rio Grande do Sul (TJ-RS) estivesse amparado em decisão do Supremo. Apesar de a jurisprudência do Supremo proclamar que as pessoas que exercem atividade notarial e registral não são imunes à tributação do ISS, porque desenvolvem serviços com intuito lucrativo, tal entendimento jamais poderia ter sido invocado pelo TJ-RS, haja vista a caracterização do trânsito em julgado em momento anterior à decisão do tribunal gaúcho. Assim, como a sentença reconheceu a não incidência tributária, esta só poderia ser contestada, dentro do prazo legal, por ação rescisória, o que, no caso, não ocorreu.

\footnotetext{
${ }^{75}$ Confira, em especial, o Decreto no 70.235 , de 1972, que regula o processo administrativo fiscal.

${ }^{76}$ De acordo com a Portaria no 52, de $1^{\circ}$ de dezembro de 2010, foram os seguintes acórdãos que motivaram a edição da mencionada Súmula: Acórdão no 101-94876, de 25/02/2005, Acórdão no 103-21568, de 18/03/2004, Acórdão no 105-14586, de 11/08/2004, Acórdão no 108-06035, de 14/03/2000, Acórdão no 102-46146, de 15/10/2003, Acórdão no 203-09298, de 05/11/2003, Acórdão no 201-77691, de 16/06/2004, Acórdão no 202-15674, de 06/07/2004, Acórdão no 201-78180, de 27/01/2005, e Acórdão no 204-00115, de 17/05/2005.

${ }_{77}$ Confira STJ, Resp no 1.415.033, rel. Min. ARI PARGENDLER, 1 a Turma. Data de julgamento: 22.10.2013.

${ }^{78}$ Confira o Acórdão referido na nota anterior.
} 
O desenho constitucional, aliado à análise casuística, revelam que o sistema não absolutiza o papel do Supremo Tribunal Federal como guardião constitucional ${ }^{79}$.

\section{CONCLUSÕES}

O Supremo Tribunal Federal, atuando como guardião da Constituição, tem a elevada responsabilidade política, social e jurídico-institucional de decidir acerca da juridicidade de determinados atos emitidos pelos demais Poderes de Estado. No exercício de seu papel constitucional, o Supremo Tribunal Federal deve ter sob perspectiva o princípio da "independência e harmonia dos poderes", com o fito de evitar invadir, por meio de suas deliberações, a esfera de atuação política dos demais poderes ou, mesmo, de impedi-los de agir no cumprimento de suas respectivas missões constitucionais.

Certamente a defesa da Constituição representa o encargo mais relevante do Supremo Tribunal Federal, pois contribui, pelo menos, para a manutenção da integridade do sistema político e a estabilidade do ordenamento jurídico. Todavia, o encargo de proteger a Constituição e a hermenêutica constitucional não se traduzem em monopólio do Poder Judiciário. $\mathrm{O}$ desenho constitucional não assegura aprioristicamente o monopólio da palavra final ao Supremo Tribunal Federal para toda e qualquer hipótese. A dinâmica institucional, que, por meio de seus efeitos emergentes, poderia revelar o contrário, igualmente não aponta para a caracterização de uma situação de monopólio. Realmente, a Lei Maior confere ao Supremo Tribunal Federal a função precípua de 'guardar a Constituição'. Entretanto, não em sentido exclusivo.

A despeito da relevante missão constitucional atribuída ao Supremo Tribunal Federal, não se sustenta o dogma de que a mais alta Corte do País detém o "monopólio da última palavra". O estudo de alguns casos concretos revela que há situações em que o Supremo Tribunal Federal não profere a última palavra em razão de diversas causas e fatores, tais como: superação de decisões do Supremo Tribunal Federal por meio de uso de mecanismos institucionais (v.g., emendas constitucionais) utilizados como meio de resposta; bloqueios institucionais internos ou externos (v.g., imutabilidade da coisa julgada, inconstitucionalidades reflexas ou

\footnotetext{
79 Decisões administrativas do Conselho Administrativo de Recursos Fiscais, embora não declarem expressamente inconstitucionalidades, por via indireta o fazem, pois continuam a negar vigência a determinadas normas jurídicas. Exemplo disso é o disposto no $\$ 4^{\circ}$ do artigo 16 do Decreto no 70.235 , de 1972 , que, em regra, tem sua vigência ofuscada pela aplicação do Princípio da Verdade Material. Cite-se parte do Acórdão no 2803-002.593-3, exarado por turma especial, na sessão do dia 13 de agosto de 2012: "[...] O princípio da verdade material no processo administrativo admite a juntada de documentos a qualquer tempo nos autos, independentemente do pedido de juntada prévio [...]” (grifos nossos). A Súmula Vinculante no 10 do Supremo Tribunal Federal é exemplar para a elucidação do ponto. In verbis: "viola a cláusula de reserva de plenário (CF. artigo 97) a decisão de órgão fracionário de Tribunal que, embora não declare expressamente a inconstitucionalidade de lei ou ato normativo do Poder Público, afasta sua incidência, no todo ou em parte".
} 
imediatas); a própria estrutura do Poder Judiciário (v.g., inércia) e o caráter hierarquizado (Supremo Tribunal Federal é órgão de cúpula).

Em razão de suas propriedades institucionais e em função da dinâmica interpoderes, o Supremo Tribunal Federal deve ser compreendido como guardião constitucional em potência, tendo em vista que a emissão de sua palavra fica subordinada à atuação de outras instituições e à configuração de determinadas circunstâncias sobre as quais exerce pouca ou nenhuma influência.

A perspectiva sistêmica sugere que a autoridade hierárquico-normativa da Constituição só é preservada se todos os Poderes constituídos se investem na função de guardiões constitucionais. Não é à toa que já se afirmou que a "Constituição é direcionada a todos, não apenas aos juízes" (SUNSTEIN, 1993, p.10).

\title{
THE MISLEADING MONOPOLY OF THE FINAL WORD
}

\begin{abstract}
Called by itself an "impartial arbiter", the Supremo Tribunal Federal has repeatedly held that it has the monopoly of the final word, when it comes to constitutional interpretation. If, on one hand, this statement demonstrates the experience of judicial supremacy, on the other it shows a presumed imbalance in the relationship among powers, which, according to the Constitution, should be harmonic and balanced. Therefore, this paper aims the investigation of the meaning and scope of the expression "final word" and how it develops in the context of a community of institutions. By enlarging the commonly studied framework, through outlining the length and depth of the addressed expression, this study does not become restricted in the manner of how the brazilian Supreme Court understands the meaning of the "last word", but it also tries to verify if other branches also proffer final words on specific issues under certain circumstances. Based on institutional theory and judicial precedents, the paper concludes that the Supremo Tribunal Federal must be understood as a potential constitutional guardian, since its decisions are subordinate to the performance of other institutions and the configuration of certain circumstances over which it exercises little or no influence.
\end{abstract}

Keywords: Institutional Dialogue. Community of Institutions. Judicial Supremacy. Separation- of -Powers. Deliberation.

\section{REFERÊNCIAS BIBLIOGRÁFICAS}

ACKERMAN, Bruce. We The People: Transformations. Cambridge, Massachusetts: The Belknap Press of Harvard University Press, 2001.

ÁVILA, Humberto. Teoria dos Princípios: da Definição à Aplicação dos Princípios Jurídicos. São Paulo: Malheiros Editora, 2005.

BALKIN, Jack. Constitutional Redemption. Cambridge: Harvard University Press. 2011 
BALKIN, Jack M. Framework Originalism and The Living Constitution. Northwestern University Law Review, 2009.

BARROSO, Luís Roberto. Judicialização, Ativismo Judicial e Legitimidade Democrática. Atualidades Jurídicas Revista Eletrônica do Conselho Federal da Ordem dos Advogados do Brasil, 2009, no 4. Disponível em: $<\mathrm{http} / /$ :www.conjur.com.br/static/text/72894,1> Acesso em 8 de junho de 2016.

BOLONHA, Carlos; Rangel, Henrique; Sepúlveda, A.G.; Carneiro, I.L.B.; Vieira, L.A. Uma Conveniente Trajetória para os Poderes: a Supremacia Executiva. Anais do XIII Simpósio Ibero-Americano de Filosofia Política: Liberdade e Poder no Mundo Contemporâneo - Universidade Federal de Juiz de Fora, V.I, p. 1-10, 2013, Juiz de Fora - MG.

BOLONHA, Carlos; LAZARI, Igor. A Conveniente Supremacia do Poder Executivo vis-à-vis a Coordenação Constitucional de Poderes. CONPEDI, 2013. Disponível em

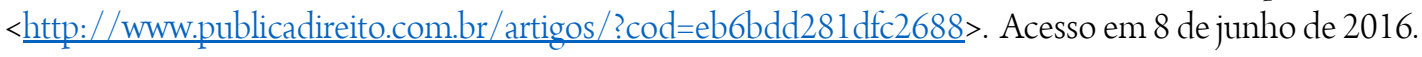

BRASIL. Ministério da Justiça. Secretaria de Assuntos Legislativos. Mecanismos jurídicos para a modernização e transparência da gestão pública. Ministério da Justiça, Secretaria de Assuntos Legislativos. V. 1. Brasília: Ministério da Justiça, 2013. Série Pensando o Direito.

CINTRA, Antônio Carlos de Araújo; GRINOVER, Ada Pellegrini; DINAMARCO, Cândido Rangel. Teoria Geral do Processo. 25 ed. São Paulo: Malheiros Editores, 2009.

GRABER, Mark. Popular Constitutionalism, Judicial Supremacy, and the Complete Lincoln-Douglas Debates. Chicago. Kent Law Review, Vol. 81, 2006.

HIRSCHL, Ran. Towards juristocracy: the origins and consequences of the new constitutionalism. Cambridge, Massachusetts: Harvard University Press, 2004.

KRAMER, Larry. The Interest of the Man: James Madison, Popular Constitutionalism, and the Theory of Deliberative Democracy. Valparaiso University Law Review, Vol. 41, No. 2. Press, 2004.

The People Themselves: Popular Constitutionalism and Judicial Review. New York: Oxford University

LARENZ, Karl. Metodologia da Ciência do Direito. Tradução de José Lamego. Lisboa: Fundação Calouste Gulbenkian, 4aed., 2005.

LECLAIR, Jean. Réflexions critiques au sujet de la métaphore du dialogue em droit constitutionnel canadien, Revue du Barreau du Québec, 2003.

MADISON, James. The Structure of the Government Must Furnish the Proper Checks and Balances Between the Different Departments. The Federalist, nº 51. Independent Journal, 1788.

MENDES, Conrado Hübner. Constitutional Courts and Deliberative Democracy. Oxford University Press, 2013.

MENDES, Gilmar. Direitos Fundamentais e Controle de Constitucionalidade. Celso Bastos Editor, 2ª ed., 1999. 
PAULSEN, Leandro; ÁVILA, René Bergman; SLIWKA, Ingrid Schroder. Direito Processual Tributário. Processo Administrativo Fiscal e Execução Fiscal à Luz da doutrina e da jurisprudência. $7^{a}$ ed. Porto Alegre: Livraria do Advogado, 2012, p. 519.

POSNER, Eric; VERMEULE, Adrian. Inside or Outside System? Chicago Public Law and Legal Theory Working Paper, nº 422. Disponível em <http:/ /lawreview.uchicago.edu>. Acesso em 8 de junho de 2016.

POSNER, Eric; VERMEULE, Adrian. Tyrannophobia. University of Chicago Public Law Working Paper, No. 276,2009 .

The Executive Unbound: After the Madisonian Republic. Oxford University Press: New York, 2010.

SEPULVEDA, A. G.; BOLONHA, Carlos; LAZARI, Igor ; Henrique Rangel ; KAYAT, R. A Convenient Path for the Brazilian Branches of Government: Executive Supremacy. Maryland Constitutional Law Schmooze Collections, 2013, Baltimore - MD (USA). Digital Commons@UM Carey Law, 2013.

SEPULVEDA, Antonio; LAZARI, Igor. Poderes Constitucionais e Lamarckismo Judicial. Julgar On Line, 2013.

SUNSTEIN, Cass. After the Rights Revolution - Reconceiving the Regulatory State. London: Harvard Press, 1990.

The Partial Constitution. Cambridge: Harvard University Press, 1993.

SUNSTEIN, Cass. VERMEULE, Adrian. Interpretation and Institutions. Chicago Public Law and Legal Theory Working Paper Series, No. 28, 2002.

TATE, Neal; VALLINDER, Torbjorn. The Global Expansion of Judiciary Power. New York: New York University Press, 1995.

VERMEULE, Adrian. Mechanisms of Democracy: Institutional Design Writ Small. Oxford: Oxford University Press, 2007.

The Atrophy of Constitutional Powers. Harvard Law School Public Law \& Legal Theory Working Paper Series, No. 11, 2007.

The System of the Constitution. Oxford: Oxford University Press, 2011.

VIEIRA, Oscar Vilhena. Supremocracia. Revista DIREITO GV 8, São Paulo: FGV, n. o 8, 2009.

Trabalho enviado em 25 de agosto de 2016.

Aceito em 05 de fevereiro de 2017. 